\title{
FÖLDRAJZ - TÁRSADALOMTUDOMÁNY - TURIZMUS: ELMÉLETI ÉS MÓDSZERTANI ÁTTEKINTÉS
}

\author{
KULCSÁR LÁSZLÓ \\ GEOGRAPHY - SOCIAL SCIENCES - TOURISM \\ A THEORETICAL AND METHODOLOGICAL OVERVIEW
}

\begin{abstract}
The geographical, regional approach, network research, and the focus on sustainability in scientific analysis is a strong incentive for scientific collaboration across disciplines. Providing a theoretical overview of the relationship between geography, social science, and tourism, this study argues that the combination of geographic, economic, and social science knowledge can make a significant contribution to the development of tourism as a scholarly field, and that beyond this it can also be useful to central and local governments in their efforts to develop tourism. Geography has a long tradition of integrating the results of other sciences, both prior to 1990 and after. The mutual exchange between geography, economics, and social sciences has been particularly pronounced since 1990 in Hungary. This does not mean, however, that the 'geographical idea' has been included sufficiently within the multidisciplinary field. Today, scientific work in which geographic approaches to social science and economics are integral is rare. Tourism may be one of the areas of analysis where this is perhaps most easily achieved. Therefore, in the future, interdisciplinary approaches in the field of tourism research need to be given much broader scope.
\end{abstract}

Keywords: geography, tourism, social sciences, theory, integrated research

Mottó: A görög történetíró, Plutarkhosz Delphi-ben egyszer találkozott a spártai Cleonbrutus-al, aki körül utazta Egyiptomot és messze lehajózott a Vörös tengeren. Megkérdezte tőle: „Barátom, miért utazol ilyen messze, hiszen nincsenek arra rokonaid, barátaid, üzleti ügyeid, nem kereskedsz arra?" Cleonbrutus azt válaszolta: „, azért, mert szeretem nézni a tájat, az embereket és tanulni abból”.

\section{Bevezetés}

Nem volt mindig magától értetődő a földrajztudomány, a társadalomtudomány és a gazdaságtudomány, azon belül a turizmus kapcsolata. Ennek oka elsősorban az volt, hogy a turizmus, mint önálló szektor elég sokáig nem jelent meg a gazdaságban. Ezt a körülményt gátolták a politikai és háborús feszültségek, bizonytalanságok és csak néhány esetben alakultak ki olyan stabil térségek, amelyek hozzájárultak a turizmus elterjedéséhez. A másik ok a földrajztudomány korábbi szemléletmódjában keresendő. A korábbi „mainstream” álláspont nem kedvezett a kialakulófélben lévo „,segédtudományokkal” való kooperációnak. Ez a helyzet, ha lassan is, de megváltozott. Ha csak az európai, s azon belül a magyar szakirodalmat tekintjük, a 18-19. században megkezdődött a földrajztudományt képviselő tudósok szemléletmódjának átalakulása. A változás először abban nyilvánult meg, hogy a földrajztudomány szorosabb kapcsolatba került a hadtudományokkal, a gazdaságtudományokkal s majd a társadalomtudományokkal. A felvilágosodás eszmeáramlatának térnyerése sok más, nem minden esetben pozitív, hatása mellett magával hozta a földrajzi, gazdasági és a történeti-társadalmi tényezők összefüggéseinek újrafelfedezését, újraér- 
tékelését kulturális, gazdasági és társadalmi-politikai szempontból egyaránt (TELEKI P. 1917/1996; DÉKÁNY I. (1922); VÁMBÉRY Á. 1906/2007; CHOLNOKY 1929/2010). Teleki a földrajzi gondolat fejlődését tárgyaló munkájában már előre jelezte a földrajz és a társadalomtudományok, különösképpen az etnográfia és a szociológia termékenyítő közeledését. Ahogyan ő fogalmazott, a természettudományok, a földrajz és a társadalomtudományok, a szociológia „,kiegyenlítődése” teremtette meg az „emberföldrajz” tudományát. Vámbéry geopolitikai elemzésében, amelyben összevetette az angol és az orosz törekvéseket az ázsiai területeken, a földrajzi tényezők mellett a kulturális sajátosságoknak tulajdonított elsődleges jelentőséget. Cholnoky hivatkozott munkája a gazdaság és természetföldrajzi leíráson túl néprajzi és az épített örökség területébe tartozó leírásokat is tartalmaz. Dékány szerint a geográfia szinte észrevétlenül ,átsiklott” a szociográfiába, mivel az utóbbinak is egyik központi kategóriája a „tér”, hasonlóképpen, mint az etnográfiának is. Mai szóhasználattal élve nincs itt másról szó, mint a regionális tudomány formálódásáról (RECHNITZER J. 1996; LENGYEL I.-RECHNITZER J. 2004). A társadalomföldrajz és a regionális tudomány kapcsolata éppen ezért nem volt mindig felhőtlen. Miután azonban a földrajztudomány differenciálódása és integrációs folyamatai különböző hullámokban, de erőteljesebbé váltak, a turizmus is megtalálta a társadalomtudományok gazdagító hatását. A jelzett diszciplínák kapcsolatának helyzete tehát folyamatosan változott s ez a folyamat még ma is tart (KóRóDI J.-Somogyi S. 1968; Beluszky P. 1989; TímÁR J. 2001; Michalkó G. 2005; MéSzÁros R. 2006). A természetföldrajzi változások gazdasági és társadalmi következményei új és új társadalomföldrajzi témaköröket vetnek fel napjainkban is. Elég csak arra gondolni, hogy a klímaváltozás természetföldrajzi sajátosságai erősen érintik a turizmus helyzetét. Egyrészt a helyi lakosság, a vállalkozók gazdasági és szociális magatartásán, a településvezetők döntésein (WYSS, R. et al. 2014) keresztül, másrészt pedig a turisztikai mozgások és általában a migráció politikai és gazdasági jellegzetességeit illetően (WEIR, B. 2017). Weir ebből kiindulva szorgalmazta a klímaváltozásokkal kapcsolatos földrajztudományi kutatások és a társadalomtudományi, turisztikai kutatások szorosabb együttmúködését.

Kicsit visszatekintve a történelembe, megláthatjuk, hogy volt azért legalább egy időszak, amikor a politikai és gazdasági körülmények kedveztek a turizmus fejlődésének. Ez pedig a római - hellén kultúrával átitatott Római Birodalom volt a császárság kezdeti időszakában. Az ókorban ekkor tapasztalható turisztikai folyamatok világosan jelezték például a történelmi és kulturális örökségek identitást erősítő, a természeti szépségekben gyönyörködtető, valamint az oktatással összefüggő utazásoknak egyben a komoly gazdasági jelentőségét is. A római birodalom „,aranykorában”, Augustus császár és néhány ôt követő császár ideje alatt általánosnak volt mondható a természeti, kulturális desztinációk, valamint a „szórakoztató központok” látogatása (LOMINE, L. 2005). Ebben az időszakban született az első görögországi ,,útikönyv” is PAUSZANIASZ (2000) tollából. A könyv a földrajzi leírások mellett a természeti, kulturális, történeti, mitológiai vonásait emelte ki a turisztikai desztinációknak, azaz a földrajzi, geológiai és etnográfiai, szociológiai leírásokat erős történeti szemlélettel egységben kezelte. A turizmus kulturális és politikai jelentőségét már igen korán felismerték az ókorban. Julius Caesar például ösztönözte az identitást fokozó történelmi helyekre való utazásokat (Trója, Karthágó), amelyek a kulturális gyökerek és a történelmi tudat erósítését szolgálták. A római elithez tartozó családok ifjai pedig „tanulmányút” keretében a görög területeken fejezték be képzéseiket. Mindennek persze komoly gazdasági jelentősége is volt, mint a korabeli vallási „turizmusnak”, például a zsidó vallási zarándoklatnak Jeruzsálembe, az ottan „kötelező pénzadománynak”, illetôleg a zarándokok költéseinek (JOHNSON, P. 2011; VARGA N. 2013), vagy jóval később a keresztény zarándoklatoknak a szent ereklyéket őrző helyekre (JoHNSON, P. 2005), vagy a gazdasági haszon érdekében már a mi korunkban a mekkai zarándoklatokat vállalkozá- 
sokba „kiszervező” muszlim vallási központoknak (GuSFIELD, J. R. 1973). A vallási turizmus, amely erôsen kötődik a természetföldrajzi vonatkozásokhoz, korunkban is töretlen népszerúségnek örvend hazánkban is (IRIMIÁs A.-MichalKó G. 2013).

Ebben a tanulmányban tehát amellett érvelünk, hogy a földrajzi és a társadalomtudományi ismeretek összekapcsolódása komoly hozzájárulást jelent a turizmussal kapcsolatos tudományos ismeretek fejlődéséhez, de egyben a turisztikai fejlesztési törekvések számára is.

\section{Elméleti és módszertani áttekintés}

A földrajzi gondolat, a tér jelentősége, mint láttuk, régóta jelen van és központi szerepet játszik a legkülönbözőbb tudományágak fejlődésében és az emberi aktivitás szinte minden területén. Egy adott tér természeti és társadalmi (kulturális) értelemben vett földrajzi jellegzetességei történetileg más jelleggel, de egyidőben mutatkoztak meg régen és ma is a társadalmi tevékenységek különböző szektoraiban. „Csupán” egymáshoz viszonyított jelentőségük, dominanciájuk változott. A politikai és hadtudományi, valamint a gazdasági és kulturális dominanciák hol kiegészítették egymást, hol konfliktusba kerültek. A földrajz mindezeket a felfogásokat, irányzatokat magához vonzotta és megjelenítette a különböző diszciplináris területein, mint például a gazdaságföldrajzban, a társadalomföldrajzban, a turizmus földrajzban, a kulturális földrajzban, politikai földrajzban stb. (BoTTLIK Zs. 2018; TímÁR J. 2009; ProbÁld F. 2007; MÉSZÁros R. 2006, 2013). CSOMÓs (2019) tanulmánya jól érzékelteti a földrajzi tudományterület ágazati besorolása körüli bonyodalmakat. Rávilágít arra is, hogy a magyar osztályozás eltér a nagy nemzetközi indexelő adatbázisok megoldásaitól. Ez szerinte nem egy marginális kérdés, hanem a tudomány fejlődésével szorosan összefügg. A társadalomföldrajz, amelynek kompetenciájába a fentebb említett földrajzi megközelítések sorolhatók, Csomós véleménye szerint nem a föld-tudományok illetékességi körét érintik, hanem a társadalomtudományokhoz tartoznak. Eltérő felfogások persze ezeken belül is megtalálhatók. JACKSON, P. (2000) például a kulturális földrajz „materializálódásának” szükségessége mellett érvel, mivel szerinte indokolatlanul háttérbe szorulnak a különböző használati tárgyak, ételféleségek, divatok, viseletek kulturális földrajzi vonatkozásai, pedig azok fontos jellemzői egy szúkebb, vagy tágabb térnek, helynek. Példa akad azért a jelenből is: AKIs, T. (2020) azt az utat járja, amit Jackson hiányolt. Egy, a kultúrára jellemző tárgy (chest - utazóláda) földrajzi vonatkozásait kísérte nyomon.

\section{A fogalmak}

A társadalomtudomány és a földrajz kapcsolatának szorosabbá válása szükségessé tette az alkalmazott fogalmak, kategóriák újragondolását. A szakirodalom arra is felhívja a figyelmet, hogy a földrajzban megszokott fogalmak jelentése az egyes térfelfogások kapcsán más - más értelmet nyer. Másrészt a társadalomtudományok is gyakran használják a földrajzi fogalmakat, jelezve azt, hogy a földrajzi - regionális nézőpontok beemelése a társadalomtudományi kutatásokba új látásmódot eredményezhet. A következőkben két földrajzi fogalmat tekintünk át példaként e változások illusztrálására.

\section{A tér és a hely}

HARVEY, D. (2006) egyik tanulmányában amellett érvelt, hogy szükséges áthidalni a földrajzi térfelfogás és a tér szociológiai felfogása közötti távolságot. Ez a törekvés lényegében azt jelenti, hogy elismerjük és elemezzük a CASSIRER, E. (1997) - féle hár- 
mas térfelfogás koncepcióját, vagyis (1) az organikus (fizikai) tér, ahol a cselekvéseink történnek, valamint (2) a bennünk kialakított térfelfogás jellegzetességeit, ahogyan saját és más terekre tekintünk és végül (3) a szimbolikusan megalkotott teret, amely ugyan a valóságban a hozzákapcsolódó szimbolikus jelentéssel együtt fizikailag nem létezik, korábban pedig vagy igen, vagy nem, de bizonyos felfogásunknak megfelelően kapcsolódik a fizikai térhez, bár lényegesen el is térhet attól. Esetünkben ennek a „híd építésnek" a tudományágak között komoly jelentősége van, mivel érthetővé válik a turizmus típusaihoz kötődő viselkedési és felfogás minták különbözősége. Az első típussal nincs különösebb baj, lényegében uralja a turizmus kutatásokat, mivel statisztikailag könnyen megjeleníthetô, legfeljebb az a probléma, hogy nem elégséges egy meghatározott térben történő, akár a turizmushoz is kapcsolódó folyamatok mélyebb elemzéséhez. Ehhez segít hozzá a tér következő felfogása, amely azt érzékelteti, hogy különbség van és nem is lényegtelen, a valóságos térfolyamatok és a „fejünkben” lévő tér között, jelentésében (térbeni kiterjedésében) és értelmezésében egyaránt (HALFACREE, K. H. 1993). A szimbolikusan megalkotott tér legismertebb területe a kulturális és a politikai antropológia. Az utóbbi keretébe tartozó példa lehet, amikor a közösségi, nemzeti identitást megteremtó, megőrző vagy erôsítő törekvések során szimbolikusan sajátjuknak tekintenek, elfoglalnak egy teret, vagy tereket kapcsolnak össze hangsúlyozva a tér általuk fontosnak tartott reprezentációját. A kulturális antropológia szintén igen erős földrajzi és történeti szemlélettel rendelkezik, s a szimbolikus térfoglalás ezekben az esetekben sokszor a történelmi, kulturális, az épített örökséghez tartozó, de identitást kifejező emlékek, tevékenységek térbeni megjelenésének hangsúlyozása.

Egy társadalomtudományi, vagy gazdaságtudományi elemzés tárgyává tett földrajzi tér talán legfontosabb jellemzője a „tér” (space) és a „hely” (place) fogalmak értelmezése. Ez nem egyszerú feladat. Ha földrajzi megközelítést hívunk segítségül, akkor azt mondhatjuk, hogy egy tágabb, földrajzi és gazdasági környezetet képzelünk el, amelynek adottságai, sajátosságai történelmileg hosszabb távon valamelyest változhatnak ugyan, de többé-kevésbé változatlanok. Ilyenek például a földrajzi és ebből fakadó gazdasági pozíciók. A tér rendelkezik természeti jellemzőkkel, amelyeket a földrajz a maga objektivitásával szemlél. Ugyanez a földrajzi tér társadalmi jellemzőkkel is bír, hiszen alapja lehet például turisztikai magatartásoknak. De hozzá tehetjük a tér demográfiai pozícióit is, azok területén tapasztalható egyenlőtlenségeket (KULCSÁR L.-OBÁDOVICS Cs. 2016). Ez utóbbi jellegzetességek akár évszázadok óta változatlanok, vagy csak alig mutatnak változást. A turizmus számára ez részben jó, részben pedig rossz hír. Jó, hiszen a természeti, történeti és kulturális örökség továbbra is jelentős vonzerővel bírhat, rossz viszont, hogy a változó gazdasági és társadalmi körülményekhez alkalmazkodni kell, ha ezt a turisztikai jelentőségét meg akarja tartani.

A „hely” (place) viszont egészen más. Földrajzi értelemben lokalizálható ugyan, de társadalmi, kulturális aktivitás nélkül üres marad. A kulturális földrajz szerint „,helyhez” nemcsak természetföldrajzi tulajdonságok vagy infrastrukturális állapotok tapadnak, hanem s ez a döntő, társadalmi strukturális jellemzők és kulturális adottságok (MiNCA, C. 2013). NEMES-NAGY-NÉMETH (2003) sem véletlenül kötötték össze elemzésükben a tér és a társadalomszerkezet, a humán erőforrás állapotának jellemzőit a „hely” és a „,fej” frappáns fogalompárral. A helynek, a térnek társadalmi jellege döntő módban esik latba a fejlesztésekkel kapcsolatban. SEBASTIEN, L. (2020) az identitás és a kötődés kategóriáit tartja kiemelkedően fontosnak a hely jellegének, érzelmi kisugárzásának meghatározásakor. Szerinte a hely jellegét affektív és kognitív jellemzők együttesen határozzák meg, s ebben a meghatározásban szerepe van a földrajzi és a társadalmi jellegzetességeknek is, amelyek nem mindig egyforma intenzitással szerepelnek a belső és a külső társadalom érté- 
kelésében, sőt azokon belül sem egységesek. A turizmus szempontjából ez igen lényeges, mert egyáltalán nem közömbös, hogy hogyan értékelik a „,hely tulajdonság - együttesét” a potenciális, vagy már tapasztalattal rendelkező turisták, azaz milyen a külsô társadalom reprezentációja az adott térségról, desztinációról, de az sem, hogy milyen képet mutatnak magukról a marketing keretében az ottélők és milyennel találkoznak az odalátogatók. E három reprezentáció egymáshoz való viszonya döntő fontosságú s ebben a természeti és gazdasági - infrastruktúrát jellemző eróforrások mellett pont az emberi és kulturális eróforrások minősége a jelentôs tényező.

\section{A távolság}

MCKERCHER, B.-MAK, B. (2019: 340) írják, hogy a földrajz első törvénye kimondja: „,minden összefügg mindennel, de a közelebb lévők jobban összefüggenek”. Számunkra ez a „törvény” két szempontból is lényeges. Az egyik az, hogy körül rajzolja a teret, amelyben a erős kapcsolatok találhatók az egyes tényezők között, s ez a „körül rajzolás” egyben a teret el is különíti a többitől. A másik fontos tényező pedig az, hogy a földrajz első törvénye nem feltétlenül igaz. Nem minden összefüggés lazul a távolság növekedésével és válik szorosabbá annak csökkenésével. Azt mondhatnánk, attól függ, hogyan értelmezzük a távolság fogalmát. A távolság fogalma tehát az egyik jó példa az eltérő értelmezésekre, mert a fogalom a különböző térfelfogások szerint maga is kulturálisan meghatározott, azaz lényegesen eltér egymástól a fizikai távolság és a kulturális távolság fogalma. MicHALKó G. (2016) is felhívta erre a figyelmet, amikor a távolságot relatív fogalomként értelmezte, beleértve a fogalom kulturális összefüggéseit is. A kulturális távolság ebben az esetben azt jelenti, hogy egy turisztikai desztináció, bár fizikailag egy meghatározott távolságban van, de mégis valaki azt közelebb érzi, más pedig távolabb. Mindez a kulturális értékrendjétől függ. Korábban említett példánkat használva tehát ha valakit a nemzeti identitás szempontjából érdekel és fontos számára egy kulturális örökség megtekintése és miliőjének átérzése, kevésbé érzi problematikusnak az odajutást annál, akit ez nem érdekel. Mindez persze abban az esetben érvényes, ha a látogatást kényszerító körülmény nem áll fenn. A helyzet ugyanaz, ha valaki érdeklődés híján nem vállalja a kirándulást szálláshelyéről egy természeti, vagy kulturális attrakció földrajzi elérésére, megtekintésére, mivel az nem tûnik számára fontosnak, nem éri meg a ráfordított időt, azaz kulturálisan messze van. ANKOMAH-CROMPTON (1992) már negyedszázada felvetették az úgynevezett kognitív távolság jelentőségét a turizmus kutatás területén. COOK-MCCLEARLY (1983) még korábban megállapították, hogy a turisták a távolságot jellemzőbben ítélik meg a kognitív tényezők, mint a fizikai tényezők (költség, idő, kilométer) alapján. Megfelelő motiváció esetén a turisták a fizikai távolságot általában alábecsülik. NYAUPANE, G. P.-GRAEFE, A.-BURNS, R. C. (2004) a turisták által megtett távolságot elsősorban az életkorral és a jövedelemmel, tehát társadalmi tényezőkkel hozták összefüggésbe. MASSARA, F.-SEVERINO, F. (2013) az úgynevezett pszichológiai távolság hatását elemezte az örökség turizmus desztináció és a kiindulópont közötti térbeli távolság ,áthidalásával” kapcsolatosan, amelynek az eredmények alapján annak közbülső (mediator) hatást tulajdonított. A pszichológiai távolság és a kulturális motiváció erős összefüggését jelezte és KULCSÁR L. et al. (2017) is, megerősítve a társadalmi tényezők, a kulturális motiváció összefüggését az örökség turizmus területén. A kulturális távolságot FAN, D. X. F. et al. (2016) három jellemzővel határozták meg. Az egyik a kultúrának tulajdonított jelentőség általában, a másik a különböző magatartási jellegzetességek és harmadikként a társadalmi jellegzetességek, mint például az iskolai végzettség vagy a jövedelem. MCKERCHER, B.-MAK, B. (2019) hasonlóképpen nem tartják feltétlen determináló tényezônek a fizikai távolság alakulását. Ő́k is az iskolai végzettség, a jövedelem, az életkor befolyásoló hatását emelik ki egy adott távolság értelmezésénél. 
A fenti néhány példa jellemzi a kutatási fogalmak eltérő megközelítését az egyes diszciplínák esetében, de azt is megmutatja, hogy az interdiszciplináris tudományos kutatások tudják kezelni ezeket az eltéréseket, az eltérô nézőpontokat, s hatásuk pozitív.

\section{A módszerek és a kutatások}

A fogalmak jelentése körüli félreértések tisztázása tulajdonképpen itt nyeri el az értelmét. Ahogy mondani szokták: „,itt van a kutya elásva”. Ha a fentiekben jelzett interdiszciplináris kutatást preferáljuk, már pedig ez fog igazán eredményre vezetni, akkor a kutatás konceptuális részében megvalósuló együttmúködés komoly erőfeszítéseket igényel a különböző tudományokhoz kötődő kutatók részéről. A kutatások során alkalmazott módszerek lehetnek földrajzi indíttatásúak, vagy gazdasági elemzések, vagy szociológiai, kulturális antropológiai jellegúek, a turizmus területén alapvetően a tér és a hely fent említett körülményeire kell koncentrálniuk.

Csomós Gy. (2019) és MészÁros R. (2013) két igen lényeges szempontra hívta fel a figyelmet. Az egyik az, miszerint a társadalomföldrajz elválik a természetföldrajztól, bár ezt a tendenciát az itthoni intézményi felfogások nem minden esetben támogatják. A másik szempont, amelynek hasonlóan komoly módszertani következményei lehetnek, a társadalomföldrajz erőteljes belső differenciálódása. Az előbbi szempont teljesen egyezik a nemzetközi tendenciákkal, félő azonban, hogy „,a fürdővízzel a gyerek is távozik”. Az egyik példa, amelyet a következókben bemutatunk arra hívja fel a figyelmet, hogy bár a társadalomföldrajz sikeres elválása a természetföldrajztól bekövetkezett, de ez nem jelentheti a tudományos együttmúködés megszúnését. A társadalomföldrajz „elaprózódása" egy természetes folyamat egyik állomásának, de nem végállomásnak tekinthetô. Ez a tendencia, amely Magyarországon már az 1960-as években megindult, ENYEDI GY. (1965), vagy LeTTRICH E. (1965), késóbb fokozatosan kiteljesedett és addig nem látott igen komoly tudományos eredményekre vezetett. Ebben a vonatkozásban is megemlíthetjük a történelmi földrajz eredményeit (BELUSZKY P. 2001, 2005; PAPP-VÁRY Á. 2016), az etnikai földrajz eredményeit (Kocsis K.-TÁtrai P. 2015; BotTLIK Zs. 2018; DEMETER G.-SzulovszKY J. 2018), a kulturális és vallási földrajzi megközelítést (TRÓCSÁNYI A.-Tóth J. 2002; DövÉNYi Z.-NÉMETH Á. 2014), a turizmusföldrajz kibontakozását (AuberT A. 2006; MichalKó G. 2016) továbbá a gazdaságföldrajz széleskörú tudományos teljesítményét (TóTH J. 2003; RÁcz T. 2014; DövénYi Z. 2016; JAKOBI Á.-LENGYEL B. 2014; SмiтH et al. 2018). Nincs hely az összes vonatkozó irodalom felsorolására, pláne azok részletesebb ismertetésére, csupán a teljesség igénye nélkül néhány példával jelezni akartuk a társadalomföldrajz sokrétú tudományos teljesítményét Magyarországon. A következőkben néhány témakört ismertetünk a vonatkozó kutatások gazdag tárházából, amelyek a tudományok között „átjárható” módszerek alkalmazásával közelítenek a turizmus multidiszciplináris elemzésének követelményeihez.

1. FoRMADI, K. et al. (2017) a turizmus kutatások egyik lényeges területeként említették a földrajzi indíttatású térségi elemzéseket, amelyek mintegy térképként reprezentálják egy meghatározott táj, nagyobb terület olyan természeti adottságait, amelyek mintegy előfeltételként és háttértényezôként szolgálhatnak a turisztikai kutatásokhoz és egyben a fejlesztési elképzelésekhez is. Ezek a módszerek, s közülük elsősorban a térinformatikai módszerek (GIS) kifejezetten a földrajztudományból kerültek át a gazdaság és társadalomtudományokba, s a turizmus területére. SinGH, P. (2015) tanulmánya jó példa arra, hogy a turizmussal kapcsolatos kutatások és fejlesztések milyen sokrétűen tudják hasznosítani a módszer lehetőségeit. Természetesen Singh tanulmányának megjelenése óta a módszer tovább fejlődött, de a lényegi vonásai megmaradtak. 
2. A látható és a nem látható geológiai folyamatok eredményeképpen létrejövő geológiai képződmények fokozott megjelenítése az érdeklődők számára létrehozta és egyre jelentősebbé teszi a geoturizmust. A történet nagyjából valamivel több mint egy évtizedes, de máris az örökség turizmus egyik dinamikusan fejlődó ága. RuBAN, D. (2015) és Soliman, M. S. A.-Abou-Shouk, M. A. (2017) elemzéseiből tudjuk, hogy a geoturisztikai kutatások 2000 előtt ritkák voltak, de 2010 után már jelentős mértékű tematikus és módszertani diverzitás jellemző rájuk. Ez azt is jelenti, hogy a geológiai képzoodmények gazdasági eróforrássá váltak és részesei lettek a turisztikai gazdaságnak. A geoturisztikához, amely az örökségturizmus keretében értelmezhető (BENTIVENGA, M. et al. 2019) hozzákapcsolódnak azok a kereskedelmi és környezetvédelmi, állagmegóvó létesítmények, amelyek szabályozzák az igénybevételt és kiszolgálják a látogatókat. A geoturizmus közelebb hozta az emberekhez a természeti képződményeket eróforrásokat, a geológiai és a tájjal kapcsolatos ismereteket, amelyek eddig kissé be voltak zárva a földtudományok szakmai terrénumába. Turisztikai helyszínként kezelve viszont beépülnek a turizmussal összefüggő gazdaság-és társadalomtudományi kutatási folyamatokba. A geoturizmus kutatása tehát szintén interdiszciplináris vizsgálódási terep.

3. A kulturális turizmus kutatásoknak külön csoportját képezik azok a vizsgálatok, amelyek hálózatként tekintenek olyan turisztikai utakra, amelyek összekötnek egyes térségeket, s a bennük lévő kulturális attrakciókat, örökség - helyszíneket. Ez a turisztikai kutatási irányzat még elég friss (GuEDES, A. S.-JiménEZ, M. I. M. 2015), de mindenképpen komoly új ismeretanyagot biztosíthat a kutatók számára. Témakörünket illetően a hálózati tudományos megközelítésnek alapvetóen három területéról beszélhetünk. Az első a turisztikai erőforrások földrajzi összekapcsolódása, amely például elképzelhetô egy lineáris turisztikai útvonal mentén, mint ahogyan ezt Guedes és Jiménez bemutatták. Megvalósulhat azonban csillag-szerúen is egy meghatározott tartózkodási helyról kiindulva. Ez utóbbi formájú hálózat tûnik gyakoribbnak. A hálózati pontok közötti kapcsolatokat alapvetően természetés gazdaságföldrajzi körülmények határozzák meg, de szociológiai és kulturális tényezők teszik élővé. Ezeknek a tényezőknek sajátosságai következtében hatnak a turistákra a vonzó faktorok, amelyek eredményesek lehetnek, ha a „közbülső akadályokat” (LEE, E. 1966) a turisták leküzdik. Erre a „földrajzi” hálózatra épül rá a turizmust múködtető szereplők hálózata, amely társadalmi és gazdasági kapcsolati tőkével rendelkezik és azt múködteti. A harmadik típusú hálózat magának a résztvevő turistáknak kapcsolati és arra épülő információs hálózata. Ez a hálózat és az abban megnyilvánuló sajátos társadalmi tőke (MASSEY, D. S. et al. 1987) és annak segítségével áramló információ meg is könnyítheti, de meg is nehezítheti a turizmust működtetô szereplők dolgát, s áttételesen az attrakciók hálózatának múködését is.

4. Az egyik leggyakrabban kutatott terület a földrajz, a társadalomtudományok és a turizmus közös területén a fenntarthatóság kérdésköre. Általában véve a fenntarthatóság fogalmát három dimenzió mentén szokták vizsgálni: a természeti, gazdasági és a társadalmi dimenziók mentén. A fogalom körül elég nagy a zűrzavar, aminek tisztázására elméletben sok kísérlet történt, a gyakorlatban azonban nem minden esetben sikerült megvalósítani a szinte mindenki által helyeselt és fontosnak tartott elveket. Ha a témánk szempontjából közelítünk a kérdéshez, talán akkor járunk a legjobban, ha elfogadjuk GonzÁLEz HERRERA, M. R. et. al. (2018: 93) által megfogalmazottokat, mely szerint a turizmus esetében a fenntarthatóság követelménye a következő: ,a helyi közösség érdekében maximalizálni a társadalmi és gazdasági hasznokat és minimalizálni az életminőséget érintố negatív hatásokat a természet, 
a gazdaság és a társadalom területén”. Az idézet egy meglehetősen normatív megközelítést takar, amelynek megvalósítása komoly nehézségekbe ütközik. A három legfontosabb domain képviselőinek számos érdekütköztetést kell menedzselni, ami nem kis feladat. A természeti örökségek védelmét vállaló és ellátó szervezetek maguk is igen komoly dilemma előtt állnak, miszerint beengedjék-e és milyen mértékben a gazdaság, az üzlet szempontjait tevékenységi körük közé, vagy nem. Hol húzható meg a fenntarthatóságot nem sértó virtuális határ e két szempont között? Ebbe az egyeztetésbe bekapcsolódnak a társadalmi domain képviselői is, mégpedig kétfelől szorítva a másik két szereplőcsoportot. Egyrészt a lokális önkormányzat és a helyi társadalom felől, másrészt a látogatók irányából. A látogatók és a tér közötti viszony, amelyet „használnak” hasonlóképpen több konfliktus forrása lehet. A konfliktusok sérthetik a szúkebb földrajzi tér fenntarthatóságának érdekeit, hiszen a természeti, vagy az épített örökség sérülhet, elhasználódhat, megfogyatkozhat. A helyi társadalom érdekében egyrészt az áll, hogy a vonzerôt képviselő természeti, múvi, szellemi, kulturális értékek ne sérüljenek, másrészt pedig életvitelük, életminőségük ne kerüljön veszélybe (Velence, Dubrovnik, Tihany stb.). Jelen van itt azonban még egy érdekmezo, mégpedig a gazdasági haszon tényezője. Más az érdeke a helyi gazdasági szereplőknek és más azoknak, akik nem helybeliek, de a turizmushoz kapcsolódó vállalkozásokat múködtetnek. Az érdekek kordinációja igen nehéz, de jó példa azért akad, mint Magyarországon Tihany esetében (Kulcsár L.-BODROGAi L. 2019). Az alapkérdés már régen felvetődött (GRAHAM, B. 2002), mégpedig a következő választás képében: tóke, vagy kultúra a nemzeti örökség? Jelenleg is ez az egyik legnagyobb dilemmája a turizmussal foglalkozóknak. Hogyan viszonyuljon e kérdéshez a társadalom, amely számára a kulturális örökség és a gazdasági teljesítmény egyaránt fontos. Erre a kérdésre a választ nem szabad megkerülni.

\section{Összefoglalás}

A 2030-ig tartó Nemzeti Turizmusfejlesztési Stratégia kifejezetten desztinációközpontú. Másként megfogalmazva földrajzi, gazdasági és társadalmi tényezőket egy meghatározott térben egységben kezelő koncepció. Megvalósulásának sikeressége felől természetesen majd a jövő dönt, de az biztos, hogy a fejlesztések térbeni helyzetét vizsgáló és azok hatását komplex módon elemző kutatások egyre kevésbé nélkülözhetők ezen a területen is. A térségi megközelítés, a hálózat-kutatások, a fenntarthatóság kérdésének a tudományos elemzések fókuszába való kerülése erős késztetést jelent a tudományos együttmúködések számára a különböző tudományágak között. A tanulmányban amellett érveltünk, hogy a földrajzi, gazdaságtudományi és a társadalomtudományi ismeretek összekapcsolódása komoly hozzájárulást jelent a turizmussal kapcsolatos tudományos ismeretek fejlődéséhez, de egyben a turisztikai fejlesztési törekvések számára is hasznosítható ismereteket nyújthat.

A földrajztudomány már régóta elindult azon az úton, amelynek keretében integrálja más tudományok eredményeit. Már 1990 előtt, de különösen 1990 után megfigyelhető a földrajztudomány és a gazdaság és társadalomtudományok egymást figyelembe vevő szemlélete hazánkban is. Ez azonban még nem jelenti a „földrajzi gondolat” multidiszciplináris mezőbe való bekerülését. Ma még ritka az olyan tudományos munka, amelyben a kutatási téma szempontjából egységet alkot a földrajzi megközelítésből származó gondolkodás a társadalomtudományi és gazdaságtudományi nézőpontokkal. A turizmus lehet az egyik olyan elemzési terület, ahol ezt talán a legkönnyebben el lehet érni. A jövő- 
ben éppen ezért a jelenleginél sokkal nagyobb teret kell biztosítani a turizmus kutatási területein az interdiszciplináris tudományos megközelítéseknek.

\author{
KULCSÁR LÁSZLÓ \\ Institute of Advanced Studies, Kőszeg \\ SOE Lámfalussy Sándor Közgazdaságtudományi Kar, Sopron \\ la.kulcsar@gmail.com
}

\title{
IRODALOM
}

AKIS, T. 2020: Emigration Chests in Ankara, Turkey: Tracing Spatial Trajectories of Tatar Community.-Space and Culture pp. 1-19.

AnKomah, P. K.-CROMPTon, J. L. 1992: Tourism cognitive distance. A set of research propositions. - Annals of Tourism Research 19. pp. 323-342.

AUBERT A. 2006: A turizmusföldrajz rendszertani helye és főbb kérdései a földrajztudományban. A turizmusföldrajz elméleti alapjaihoz. - Földrajzi Értesító 55. 3-4. pp. 333-354.

BeluszKy P. 1989: Magánjelentés a (társadalom) földrajzról. - Tér és Társadalom 1. pp. 49-65.

Beluszky P. 2001: A Nagyalföld történeti földrajza. - Dialóg Campus Kiadó, Budapest-Pécs. 274 p.

Beluszky P. 2005: Magyarország történeti földrajza. - Dialóg Campus Kiadó, Budapest-Pécs. 462 p.

Bentivenga, M.-Cavalcante, F.-Mastronuzzi, G.-Palladino, G.-Prosser, G. 2019: Geoheritage: The Foundation for Sustainable Geotourism. Geoheritage 11. pp. 1367-1369.

BоттLIK Zs. (szerk.) 2018: Etnikai földrajzi kutatások Köztes-Európában. - ELTE Természettudományi Kar, Budapest. 256 p.

CASSIRER, E. 1997: Politikai antropológia. - Osiris Kiadó, Budapest. 218 p.

CHolnoky J. 2010: Magyarország földrajza. - Kráter Kiadó, Budapest. 529 p.

COOK, R. L.-K. W. MCCLEARY 1983: Redefining Vacation Distances in Consumer Minds. - Journal of Travel Research 21. pp. 31-34.

Csomós Gy. 2019): A társadalomföldrajz tudományrendszertani besorolásának hazai és nemzetközi gyakorlata. - Földrajzi Közlemények 143. 1. pp. 1-11.

DEMETER G.-SzULOvSZKY J. (szerk.) 2018: Területi egyenlőtlenségek nyomában a történelmi Magyarországon. Módszerek és megközelítések. - MTA BTK - Debreceni Egyetem, Budapest - Debrecen. 338 p.

DÉKÁNY I. 1922: Geográfia és szociográfia. Bethlen Gábor Irodalmi és Nyomdai Részvénytársaság, Budapest.

DövÉNYI Z.-NÉMETH Á. 2014: A vallási diverzitás változása Magyarországon 2001 és 2011 között. - Területi Statisztika 54. 6. pp. 550-573.

DöVÉNYI Z. (szerk.) 2016: A Kárpát-medence földrajza - Akadémiai Kiadó, Budapest. 1352 p.

ENYEDi Gy. 1965: A mezőgazdaság földrajzi típusai Magyarországon. Földrajzi Tanulmányok 4. - Akadémiai kiadó, Budapest. $71 \mathrm{p}$.

Fan, D. X. F.-Zhang, H. Q.-Jenkins, C. L.-Lin, P. M. C. 2016: Does social contact lessen perceived cultural distance? Evidence from tourist-host social contact. - Annals of Tourism Research 61. pp. 223-225.

Formadi K.-MAYER P.-PÉNZES E. 2017: Geography of Tourism in Hungary. In: WidAWSKI, K. - WYRZYKOWSKI, J. (eds.), The Geography of Tourism of Central and Eastern European Countries. - Springer International Publishing AG. pp. 189-32.

González Herrera, M. R.-Sasidharan, V.-Hernández, J. A. A.-Herrera, L. D. A. 2018: Quality and sustainability of tourism development in Copper Canyon, Mexico: Perceptions of community stakeholders and visitors. - Tourism Management Perspectives 27. pp. 91-103.

Graham, B. 2002: Heritage as Knowledge: Capital or Culture? - Urban Studies 39. 5-6. pp. 1003-1017.

GuEDES, A. S.-JIMÉNEZ, M. I. M. 2015: Spatial patterns of cultural tourism in Portugal. - Tourism Management Perspectives 16. pp. 107-115.

Gusfield, J. R. 1973: Tradition and Modernity. In: Etzioni, A. -Etzioni-Halevy, E. (eds): Social Change. New York Basic Books, New York.

HALFACREE, K. H. 1993: Locality and Social Representation: Space, Discourse and Alternative Definitions of the Rural. - Journal of Rural Studies 9. 1. pp. 23-37.

HARVEY, D. 2006: The Sociological and Geographical Imaginations. - International Journal of Politics, Culture, and Society 18.3-4. pp. 211-255.

IRIMIÁs A.-MichalKó G. 2013: Religious tourism in Hungary - an integrative framework. - Hungarian Geographical Bulletin 62. 2. pp. 175-196. 
JACKSON, P. 2000: Rematerializing social and cultural geography. - Social \& Cultural Geography 1. 1.pp.9-14. JAKOBI Á.-LENGYEL B. 2014: Egy online közösségi háló offline földrajza, avagy a távolság és a méret szerepének magyar empíriái, - Tér és Társadalom 28. 1. pp. 40-61.

Johnson, P. 2005: A kereszténység története. - Európa Könyvkiadó Budapest. 400 p.

Johnson, P. 2011: A zsidók története. - Európa Könyvkiadó, Budapest. 760 p.

Kocsis K.-TÁTRAi P. (szerk.) 2015: A Kárpát-Pannon térség változó etnikai arculata. 3. kiadás. - MTA CSFK Földrajztudományi Intézet, Budapest. 35 p.

KóRóDi J.-SomogYi S. 1968: Idegenforgalmi Földrajz I-II. Budapest: - Közgazdasági és Jogi Könyvkiadó, Budapest. 619 p.

KulcsÁr L.-Bodrogai L.-Vizi I. G. 2017: Tourism development and cultural heritage: the stakeholders' opinion on the role of the restored Esterházy palace in Western Hungary. - Economic thought and practice 26. 22. pp. 813-827.

KulcsÁr L.-BODROGAi L. 2019: Fesztiválturizmus és fesztiválgazdaság: Tihany és Fehérvárcsurgó összehasonlító vizsgálata. - Prosperitas 4. pp.

Kulcsár L.-ObÁdovics Cs. 2016: Népességdiamika és társadalmi szerkezet. - Területi Statisztika 56. 4. pp. 390-414.

LEE, E. 1966: A Theory of migration. - Demography 1. 47-57.

LENGYEL I.-REChNITZER J. 2004: Regionális gazdaságtan. - Dialog Campus, Budapest-Pécs. 391 p.

LETTRICH E. 1965: Urbanizálódás Magyarországon. Földrajzi Tanulmányok 5. - Akadémiai kiadó, Budapest. $89 \mathrm{p}$.

Lomine, L. 2005: Tourism in Augustan Society (44 BC-AD 69). In: Walton, J.K. (ed): Histories of Tourism: Representation, Identity and Conflict. - Channel View Publications Clevedon, Buffalo-Toronto. pp. 69-87.

MASSARA, F.-SEVERINO, F. 2013: Psychological distance in the heritage experience. - Annals of Tourism Research 42. pp. 108-129.

Massey, D. S.-Alarcon, R.-Dudand, J.-Gonzales, H. 1987: Return to Aztlan: The social process of international migration from Western Mexico. - University of California Press, Berkeley.

MCKeRCHER, B.-MAK, B. 2019: The impact of distance on international tourism demand. - Tourist Management Perspectives 31. pp. 340-347.

MÉszÁRos R. 2006: A társadalomföldrajz és a regionális tudomány Magyarországon. - Magyar Tudomány 1. pp. 21-28.

MéSzÁRos R. 2013: A társadalomföldrajz jövőjének megközelítései. - Magyar Tudomány. 7. pp. 866-873.

MichALKó G. 2005: A humánökológia szerepe a magyarországi turizmusföldrajz modernizációjában. - Turizmus Bulletin 9. 1. pp. 32-42.

MichalKó G. 2016: Turizmológia elméleti alapokon. -Akadémiai Kiadó, Budapest. 266 p.

MincA, C. 2013: The cultural geographies of landscape. - Hungarian Geographical Bulletin 62. 1. pp. 47-62.

Nemes-NAgy J.-Németh N. 2003: A „hely” és a „fej”. A regionális tagoltság tényezői az ezredforduló Magyarországán. Budapesti Munkagazdaságtani Füzetek. 7. - MTA Közgazdaságtudományi Kutatóközpont Munkaerőpiaci Kutatások Múhelye, Budapest. 175 p.

Nyaupane, G. P.-Graefe, A.-Burns, R. C. 2004: Does distance matter? Differences in characteristics, behaviors, and attitudes of visitors based on travel distance. In: MuRDY, J. (ed.): Proceedings of the 2003 Northeastern Recreation Research Symposium. Gen. Tech. Rep. NE-317. - Newtown Square, PA: U.S. Department of Agriculture, Forest Service, Northeastern Research Station. pp 74-81.

PAPP-VÁRY Á. 2016: A magyar egyházi közigazgatás térképei, In: GÁL A.-FrisNYÁK S.-KóKAI S. (szerk.): A Kárpát-medence történeti vallásföldrajza, 1. kötet. - Nyíregyházi Egyetem Turizmus és Földtudományi Tanszéke, Nyíregyháza. pp. 191-198.

Pauszaniasz 2000: Görögország leírása I-II. - Pallas Stúdió, Attraktor Kft., Budapest. 757 p.

PROBÁLD F. 2007: Társadalomföldrajz és regionális tudomány. - Tér és Társadalom 21. 1. pp. 21-33.

RÁCZ T. 2014: Crossdisciplinarity or Tourismology? The Scientific Identity of Tourism in Hungary. In: BUTOWSKI, L (szerk.): Searching for the Scientific Identity of Tourism Research. -School of Tourism and Hospitality Nanagement, Warsaw. pp. 35-57.

RECHNITZER J. 1996: A regionális tudomány helyzete. - Tér és Társadalom 2-3. I-XII.

RuBAn, D. A. 2015: Geotourism - A geographical review of the literature. - Tourism Management Perspectives 15. pp. $1-15$.

SEBASTIEN, L. 2020: The power of place in understanding place attachments and meanings. - Geoforum 108. pp. 204-216.

SINGH, P. 2015: Role of geographical information systems in tourism decision making process: a review. - Information Technology \& Tourism.15. pp. 131-179.

Smith, M. K.-Egedy, T.-Csizmady, A.-Jancsik, A.-Olt, G.-Michalkó, G. 2018: Non-planning and tourism consumption in Budapest's inner city. Tourism Geographies: An International. - Journal Of Tourism Space Place And Environment 20. 3. pp. 524-548. 
Soliman, M. S. A.-Aвоu-Shouk, M. A. 2017: Predicting Behavioural Intention of International Tourists Towards Geotours. - Geoheritage 9. pp. 505-517.

TELEKI P. 1996: A földrajzi gondolat története. - Kossuth Könyvkiadó. 193 p.

TímÁR J. 2001: A modern társadalomföldrajz szemlélete és módszerei. In: NEMEs NAGY J. (szerk.): Geográfia az ezredfordulón. Regionális Tudományi Tanulmányok 6. - ELTE Földrajz Tanszékcsoport, Budapest.pp. 49-60.

TímÁR J. 2009: Communist and post-communist geographies. In: KITCHIN, R.-ThrifFT, N. (eds): The International Encyclopedia of Human Geography 2. - Elsevier, Oxford. pp. 214-220.

Tо́тн J. (szerk.) 2003: Általános társadalomföldrajz I-II. - Dialóg Campus Kiadó Budapest-Pécs. 519 p.

TRócsánYi A.-Tóth J. 2002: A magyarság kulturális földrajza II. - Pro Pannonia Kiadó, Pécs. 361 p.

VÁMBÉRY Á. 2007: A nyugat kultúrája keleten. - Lilium Aurum Kiadó, Dunaszerdahely. 417 p.

VARGA N. 2013: A Biblia és a Korán politika- és gazdaságképe. - EXIT Kiadó - Marczibányi téri Múvelődési Központ, Kolozsvár - Budapest. 168 p.

WEIR, B. 2017: Climate change and tourism - Are we forgetting lessons from the past? - Journal of Hospitality and Tourism Management 32. pp. 108-114.

Wyss, R.-ABegG, B.-Luthe, T. 2014: Perceptions of climate change in a tourism governance context. - Tourism Management Perspectives 11. pp. 69-76. 